This is an electronic reprint of the original article. This reprint may differ from the original in pagination and typographic detail.

Author(s): Kiss, Attila

Title: $\quad$ Teaching the Romanian neighbors Hungarian: language ideologies and the Debrecen Summer School

Year: $\quad 2016$

Version:

Please cite the original version:

Kiss, A. (2016). Teaching the Romanian neighbors Hungarian: language ideologies and the Debrecen Summer School. Multilingua : Journal of Cross-Cultural and Interlanguage Communication, 35(1), 31-55. https://doi.org/10.1515/multi-20141030

All material supplied via JYX is protected by copyright and other intellectual property rights, and duplication or sale of all or part of any of the repository collections is not permitted, except that material may be duplicated by you for your research use or educational purposes in electronic or print form. You must obtain permission for any other use. Electronic or print copies may not be offered, whether for sale or otherwise to anyone who is not an authorised user. 
Attila Gyula Kiss*

\title{
Teaching the Romanian neighbors Hungarian: language ideologies and the Debrecen Summer School
}

DOI 10.1515/multi-2014-1030

\begin{abstract}
This article is a contribution to the hitherto scant literature on learning a historical minority language and on language ideologies in the context of a study abroad program in Hungary, Debrecen. I analyse the language ideologies of the decision makers in Hungary and in the Debrecen Summer School in relation to the teaching of Hungarian to the neighboring peoples. Drawing on interactional data of participants from Romania, the perspective of learning Hungarian as a historical minority language is examined. The present article combines a historical approach with language ideologies by focusing on an institution offering language education. Language ideologies are presented as they appear in the larger historical discourses, contemporary documents, and media interviews. I briefly outline the major turning points in the history of the institution which also reflects the changing language ideologies and cultural politics of Hungary. The qualitative discourse analysis of interviews and the conclusion of this ethnographic study demonstrate that language ideological positions in relation to the teaching and learning of Hungarian have been firmly located in historical and cultural contexts. Discourse analysis of various data demonstrates that, on the one hand, the course providers have espoused competing ideologies of who the learners should be as well as how to present the country and the culture, while, on the other hand, showing that the learners have had to negotiate prejudice and stereotype rooted in discourses about the often burdened history.
\end{abstract}

Keywords: language ideologies, historical minority language, study abroad, discourse study, learning Hungarian, Romania

\section{Introduction}

The voluntary learning of a historical minority language in general, and in the former Eastern Bloc in particular, has been neglected both as a subject of study

*Corresponding author: Attila Gyula Kiss, Department of Art and Culture, University of Jyväskylä, Jyväskylä, Finland, E-mail: attilagyulakiss@yahoo.com 
and as a practical tool to foster tolerance between cohabiting and neighboring ethnicities. Nonetheless, such a need has been noticed, for instance by EU institutions (Rindler Schjerve and Vetter 2012: 34-35). My study will address this question both from a theoretical and practical point of view.

A historical minority language is a language that is spoken in a state, typically before its establishment, or before the annexation of a territory, and not one that has come to be spoken due to recent immigration. Furthermore, the language is considered to be in minority status typically due to measures implemented in modern nation building, where the hegemony and dominance of the majority culture and language are enshrined in the constitution and other laws (see May 2012). Previously, (Kiss 2012, 2013) I investigated the learning of a historical minority language (Hungarian) in Romania. In this article, I examine the learning of the historical minority language abroad, that is, in the country where that language is the official language (Hungary). Previous Study Abroad (Kinginger 2009) studies present a wide variety in settings, origins and destinations, languages studied, number of participants described in the studies, and the focus or method of the analyst. Block (2007) points out that there is a disproportionate emphasis in such studies on the experiences of American students. The present article applies this Study Abroad setup to an institution where Hungarian is taught for Romanians in Debrecen, Hungary. That is, I present reflections on a summer course that bears the Hungarian name nyári egyetem (summer university), denoting higher education, whereas Romanian participants refer to it as curs de vară (summer course), connecting it to voluntary learning.

Long (1997: 320) argues for "a broader, context-sensitive, participant sensitive, generally sociolinguistic orientation" for Second Language Acquisition research. Spolsky (2011: 172) in turn urges the inclusion of "ethnically motivated second-language teaching" in such ventures as well. This article examines a specific Study Abroad perspective, where the speakers of a neighboring language are the target learners, and where the target language is a historical minority language in the neighboring country. In the Study Abroad setup, discussion of such learning is scarce, often limited to footnotes (e.g. MurphyLejeune 2002). However, in the general framework of learning historical languages, there have been a number of studies in the Western European context focusing on regional and autonomous settings (on learning Basque, see Azkue and Perales 2005; on learning German in South Tyrol, see Cavagnoli and Nardin 1999). So far, few attempts have been made to present the complexities of voluntary learning in East Central European contexts (but see Jaworska 2009) in general, and in the Romanian context where Hungarian is a major historical minority language in particular (but see Marton and Vincze 2011). 
Various previous studies on learning historical minority languages (e.g. Blackledge 2002; Brogden 2009; McEwan-Fujita 2010) suggest that language ideologies are central to understanding issues involved in the learning and teaching of the language of a historical minority. Language ideologies are defined as "cultural, metapragmatic assumptions about the relationship between words, speakers, and worlds" (Gal 2006: 388). In a similar vein, Lantolf and Pavlenko (2001) point out that language study should always be tied to concrete historical and sociocultural settings and the vast multiplicity of semiotic resources within them. The implications of language ideologies for learners can be far-reaching since they often serve as a frame for linguistic practices as well (cf. Blommaert 2006). Equally important is the fact that language ideologies also offer insights into "the microculture of communicative action" and to "political economic considerations of power and social inequality, confronting macrosocial constraints on language behavior" (Woolard and Schieffelin 1994: 72).

In my study, I unravel a set of political positions and cultural notions in the anthropological sense (e.g. Talburt and Stewart 1999) that are linked to teaching Hungarian to the titular speakers of the neighboring countries. Titular here means the dominant ethnolinguistic group of a country, typically after which the state has been named in East Central Europe, too, such as Slovaks (Slovakia), Serbs (Serbia), Croats (Croatia), and Romanians (Romania). More specifically, I look into the conceptions of Romanian speakers in respect of learning Hungarian.

First, the aim of this article is to examine the Debrecen Summer University (hereafter DSS) and its relationship towards teaching Hungarian to the titular ethnicities of the neighboring countries, with a focus on native Romanians. The city of Debrecen is situated only $60 \mathrm{~km}$ from the Romanian border. Hungary and Romania have had a historically burdened relationship, and Romania is home to the largest (c. 1.3 million) Hungarian minority population today. Due to its proximity to the Romanian border, the DSS may be the place where significant numbers of Romanian first language speakers are able to study the Hungarian language. In the second part of my article I present a discourse analysis of interactional data in order to unravel language ideologies in this European border region (for a similar focus and discussion on another historically burdened area and the learning of German in Poland, see Jaworska 2009).

Focussing on the recent past (2009-2011) and the present, I will base my analysis on data from newspaper and television interviews with Romanian participants that have been published or broadcast. I am looking for answers to the following questions: Who has studied Hungarian at Debrecen? Why have Romanian native speakers attended the DSS? What was their general impression 
of the program? I draw on Heller's argument (2007) in the analysis of Frenchlanguage minority schools. According to Heller, it is useful to to examine "discursive practice for understanding basic dimensions of social organization, and for understanding them as process and not as object” (2007: 651). Following Heller (2007), my intention is to analyzee the historical trajectories in the DSS as a discursive space, alongside the interests and mobilized resources that framed the distributed knowledge in the case of the DSS and in relation to language learners from the neighboring countries.

\section{Site of research}

In the context of the Austro-Hungarian Monarchy, Gal points out that "the multilingualism of the nineteenth century was quite different as an ideology and practice than the multilingualism of the current era" (2011: 32). That is, the learning of each other's language(s) was a general practice. However, this practice largely disappeared in the twentieth century. The need to facilitate multilingual and multicultural competence is most evident in the successor states of the Austro-Hungarian monarchy where ethnic tensions and nationalizing policies have made even economic cooperation between the neighboring states difficult.

The site of study for the present article is an adult training institution, the DSS in Hungary, which has received many thousands of language learners from all over the world throughout its 85 years of existence. The institution offers short term intensive language courses. For a long time it has been the most important institution with a declared goal to teach Hungarian as a foreign and a second language. The DSS has been a part of the University of Debrecen for most of its existence. The second or third largest city in Hungary, Debrecen is situated in the eastern part of the country in the Great Plains region, next to Hortobágy Puszta. The city of Debrecen has supported the DSS from early on, since it has brought significant revenue for the city by attracting numerous foreign visitors.

\section{Approach}

Language learning abroad has been studied from a variety of research traditions; for instance, language acquisition, measurement of proficiency, ethnographic studies, and language socialization and identity (see Kinginger 2009). A popular way to study the bilingual development of participants in a study 
abroad setting is to carry out a case study on autobiographical accounts (e.g. Menard-Warwick and Palmer 2012). However, my project examines a more complex phenomenon with respect to many agents, multiple perspectives, and historical development. Inspired by Scollon \& Scollon (2004), my intention is to present an institutional ethnography. Rather than a case study, the DSS presents a nexus (Scollon and Scollon 2004) of activities and discourses in time and space.

I locate the language ideological discourses in their changing historical contexts. That is, I adopt a historical perspective (cf. Heller 2007; Scollon and Scollon 2004) in examining the DSS from its foundation to the present. A similar historical approach was adopted by Mar-Molinero (2006) in her study on the Instituto Cervantes, in Lawson's (1995) description of the People's College, and in Wünsch's (2004) study on the Comission for Intellectual Cooperation, the latter two institutions founded in the same period as the DSS (1921 and 1922, respectively). The practices of the DSS were informed and often governed by politics in Budapest. Thus, the institution also reflects the changing language ideologies and cultural politics of Hungary.

I follow a concept of ethnography developed by Geertz (1973), who considers it more a viewpoint than a method. In the study of the complexities and particularities of social scenes, Geertz aimed at "thick description". The ethnographic approach of stressing the open-ended nature of research aims at "getting quality from the actor's point of view" (Atkinson 2005: 50), which is particularly congruent with the approach of language ideologies.

In creating an institutional ethnography, I use the perspective of anthropological sociolinguistics, applying ethnographical data collection and analysis methods as outlined by Heller (2008) and Blommaert and Jie (2010). Therefore, I take the interpretivist stance of linguistic ethnography, describe practices of the leaders of the institution, and address questions to shed light on language ideologies. I use Discourse Analysis as complementary to ethnography.

I collected a wealth of data ranging from archived documents, publications, posters, and media reports - stretching over several decades - as well as seven semi-structured interviews with Romanian DSS participants, totalling approximately five hours of recorded data. These serve as the backround for this article; however, their detailed analysis has been left for a later occasion. In this article, I have chosen to analyse one television interview, which I consider especially significant since it presents rare data on how Romanian speakers discuss among themselves the issue of learning Hungarian at the DSS and the interlocutors have a Romanian-speaking television audience in mind. As such, it offers a more detailed and concise representation of the language ideologies under study than do the individual interviews carried out by the author (cf. Kiss 2012). 
In a qualitative analysis based on various texts, I will outline the major turning points in the history of the institution. Based on interview data, I explore the language ideologies of Romanians studying at the DSS. I use the interpretative framework of language ideologies and analyse the discourses about learning Hungarian at the DSS with a focus on the presumptions they point to. I will also look in particular at what value Romanians attach to learning Hungarian, and in general, their relationship to the study of Hungarian at the DSS. Methodological similarities can be found with other SA studies that use discourse analysis (Hashimoto 1993), or ethnography (Talburt and Stewart 1999).

I analyze semi-structured interviews (see Ten Have 2004 for different interview types).

In the analysis of the interviews, I also look at "patterns of discourse as they emerge in interaction", and as "primary acts of meaning-making” (Heller 2001: 251). I use an integrative approach (Heller 2008), looking at larger social and historical processes and structures beyond the interaction too. Interactional data is also used in Heller (2011), largely from the discourse analytic perspective of analyzing the content of turns by different actors; however, Laihonen (2008; see also Ten Have 2004) brings together insights from Language Ideologies and Conversation Analysis in order to show how the contents and details of shifts in interaction are actually co-constructed and how language ideas are intertwined with the interactional structure in interviews.

\section{The Romanian participants at the Debrecen Summer School}

To a varying extent, the teaching of Hungarian for the speakers of the titular languages in the neighboring countries has been present among the intentions of the DSS, supported by government ideologies, drafted in bilateral agreements, and enhanced through scholarships. I focus on trends that for the most part were explicitly expressed by institutions of the Hungarian government. While the history of the DSS is relatively well documented (see Némedi 1988), no description of its relation to the neighboring countries is available. This is particularly true in relation to Romania.

We were able to identify different periods in the teaching of Hungarian at the DSS. All of them were significantly influenced by the prevailing cultural politics of a particular period. In the first period, from the establishment of the DSS in 1927 up to the Second World War, the programs were designed keeping in mind the cultural politics of the interwar period, which aimed at the greater 
visibility of Hungary among the friendly Western nations: Italy, Germany, and Austria. In practice, this meant that the emphasis was on lectures in a number of international languages on topics about Hungarian culture and language. Little attention was devoted to language teaching as such. The audience was made up of intellectuals, students, and "lay people", mostly ethnic Hungarians from the neighboring countries or from the Western diaspora. Representatives of the neighboring ethnicities, with the exception of Austrians (Germans), were not targeted as potential participants. Some neighboring cultures, such as Romanians or Slovaks, were considered inferior in the hierarchy of cultures and languages at the time, and their representatives were accordingly absent from the organized summer courses. The number of participants steadily grew and reached record numbers that would be surpassed only in the early 1990s.

In the interwar period, Hungarian cultural policy served the goal of revising the Treaty of Trianon (June 4, 1920), whereas in the socialist period the overriding doctrine was internationalism. In the socialist period, dominant language speakers from the neighboring countries began to attend the DSS in more significant numbers, and the activity of the DSS was heavily influenced by the ideas of socialist neighborhood cooperation. There were attempts to broaden the spectrum towards the working class of these countries. However, in reality, the core group of participants, the intellectual type, remained dominant. The programs and the media representations of the DSS reflect the contemporary propaganda purposes of the age.

Before proceeding to a detailed discussion, a brief overview of the number of Romanian citizens at the Debrecen Summer School is provided. According to Némedi's history of the institution (1988: 174-176), there were no titular language speakers of the neighboring countries among the participants between the years 1927 and 1959, with the exception of Austrians who first came in 1935.

Figure 1 shows the numbers and the percentages of Romanian citizens as compared to the total number of participants. It must be taken into account that there is no way to find out how many of the participating Romanian citizens were Hungarian first language speakers, or whether they had any prior competence in Hungarian. Between the years 1927 and 1961, we know of only one, while in the first half of the 1990s (1990-1994) there is no data about Romanian first language participants. In the period between 1962 and 1990, the number of participants from Romania remained low; in the latter part of the 1980s, it dropped further. After 1990, along with the general increase in the number of participants, there was an increase too in the numbers of those coming from Romania.

The newspaper of the DSS, Nyári Egyetem, also shows that the editors were interested in the neighboring countries when reporting on the trends of the mid- 


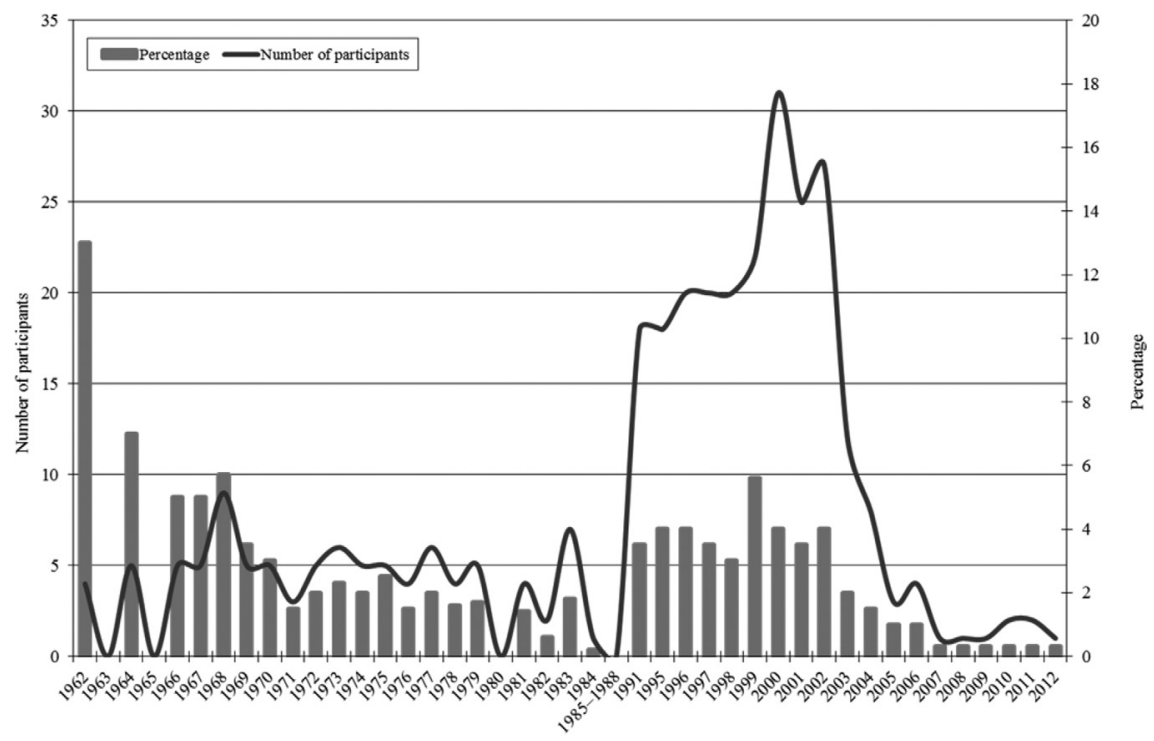

Figure 1: The number of Romanian citizens and their percentage among the total number of participants at the DSS in the given year: Sources: 1927-1988: Némedi (1988: 174-176); 1995-2011: Igazgatói jelentések 2001-2011.

1990s. In 1996 they remark that "The largest numbers are coming from Central and Eastern Europe. From the eleven countries in this particular area 115 people attended our Summer School (66 from our neighboring countries of whom 35 were native speakers of Hungarian)" (Résztvevők... 1996).

Among the neighboring countries, in the late 1990s, most participants hailed from Austria while the fewest in number came from the Ukraine. The highest number of self-funded participants also came from Austria. This becomes obvious when we look at the statistics of the distribution of participants in the non-subsidized winter and spring courses of the same period. Virtually no participants from the former socialist neighboring countries attended any of these non-subsidized courses (Résztvevök... 1999). One of the reasons, beyond the lack of funds, could be found in the political atmosphere of the 1990s, when, as Verdery remarks (1996: 100), Romanian national sentiments collided with the nationalism of Hungarians once again.

As is evident from Figure 1, in the 1990s there were approximately 20 participants from Romania whose first language was Hungarian. These were mostly students from the Department of Hungarian Language and Literature at the Babeș-Bolyai University in Cluj-Napoca. From 2000 to 2005 there were between nine and 18 students whose first language was Romanian. From 2005 
their number dwindled to one or two at the summer courses. Another scholarship is available for the inhabitants of the twin cities of Debrecen, which in the case of Romania is Oradea. This shows that the city recognizes the efforts of the DSS in attracting visitors to the city. The following Table 1 shows the number of Romanians at the summer courses:

Table 1: Romanian first language speakers at the DSS.

\begin{tabular}{rrrrrrrrrrrrr}
\hline 2000 & 2001 & 2002 & 2003 & 2004 & 2005 & 2006 & 2007 & 2008 & 2009 & 2010 & 2011 & 2012 \\
\hline 13 & 19 & 16 & 10 & 9 & 3 & 3 & 2 & 1 & 1 & 3 & 2 & 1 \\
\hline
\end{tabular}

Source: Registration forms of the DSS office.

According to the staff of the DSS, the numbers reflect the number of scholarships offered by the Hungarian Scholarship Board. On the basis of the registration forms and internal statistics of the DSS, there has been a constant reduction in scholarships generally. In the early 2000s, there were a total of 180-200 scholarship holders at the Debrecen course, with their number dwindling in 2011-2055.

The language teaching literature contains brief remarks about teaching Hungarian in Romania itself. Sources report that there is only modest interest on the part of Romanians and that the main site of teaching Hungarian in Romania is the Department of Hungarian Studies at the University of Bucharest (Péntek 2002; Kádár 2008). Molnár, the head of the aforementioned Department in the late 1990s, states that Romanian nationalism has for a long time nourished prejudice, stereotypes, and negative images of Hungarian language and culture (2000: 211). In his view, in order for language learning to be succesful, these images should first be dismantled. The DSS seems to have succeeded in this from time to time. For instance, the director's report from 2002 (Igazgatói jelentés) contains the following passage: "In respect of the development of relations between Romania and Hungary we consider it very important that there are more and more Romanian native speakers that study at our Hungarian courses”.

A significant number of students came from the Hungarian Studies program in Bucharest. The peculiarity of this department was that it enrolled both Hungarian native speakers and Romanians who began studying the language there (see Murvai 2010). Both groups attended courses at the DSS. According to the registers of the DSS, another group of students came from the Valahia University in Târgoviște in the early 2000s. In that particular region of Romania, Hungarian is not present in everyday life. The students from this university were history majors and for the most part were absolute beginners 
at learning Hungarian. This pattern would suggest that they were organized groups and the students were referred to the DSS by their instructors. Their attendance in a Hungarian course is in line with Szilvási's (2011: 95) report on Hungarian language learners in Slovakia, and confirms the pattern that in the territory of the former Greater Hungary a knowledge of Hungarian is still indispensable for professions dealing with historical topics. Szilvási points out that at certain Slovak universities and for a number of study fields such as history, ethnography, and archival science, Hungarian is a compulsory course subject. That is, the motivation of these students to learn Hungarian is instrumental and we do not know whether they continued their study afterwards.

\section{Romanian speaker participants'recent reflections on the DSS}

In the following section I will look at two interviews with Romanian learners of Hungarian. The first was published in the periodical of the DSS, Nyári Egyetem, which regularly carried language learner biographies and interviews with participants. The interview was edited by the journalist (Dudics) and the editor, and was published in Hungarian. Because of the level of constructedness of this interview, it provides a glimpse into how the Hungarian editors constructed this Romanian learner. According to the interview (Dudics 2003: 8), Emilia (the names in the interviews are pseudonyms) attended the course in 2003 and was one of the many interpreters and translators from Brussels who studied Hungarian in preparation for Hungary's ascension to the European Union, which took place in 2004. These interpreters typically already had a multilingual repertoire and were highly sophisticated in their language learning approach.

Emilia says that her mother tongue is German, but she also speaks Romanian, because she was born in Târgu-Mureș (in Hungarian Marosvásárhely). When asked why she studies Hungarian, she relates that it has been the result of a longer process: "For a time I started to interpret from Romanian and I became interested in returning to my roots. I lived in Romania for twelve years, where I attended German language education. On the street, however, we spoke Romanian for most of the time. I very often heard Hungarian being spoken, so I consider this (language) as part of my past" (Dudics 2003: 8). She says that it was not necessary for her to start learning the language from the basics because she remembered a lot of things: "the start was a little easier for me, since I understood more than the others" (Dudics 2003: 8). She explains that Hungarian is present in the everyday language environment for Rumanians living in Transylvania, but 
that they often find it difficult to read or write because they never took part in regimented studies. When asked about her previous knowledge of Hungary and Hungarians, she states that she knew very little about either before going to the DSS.

(1) Interviewer: Mennyit hallottál korábban Magyarországról? 'How much have you heard about Hungary?'

Emilia: $\quad A z$ az igazság, hogy régen nem tudtam túl sokat a magyar kultúráról és történelemről. Budapesten vannak ugyan rokonaim, de korábban nem érdeklődtem Magyarország iránt. A Balaton, a magyar konyha és a zene mindig tetszett, de ezek szokásos dolgok. A romániai iskolában sem lehetett túl sokat megtudni Magyarországról, sőt, a “szomszéd” mindig kicsit gonosznak vagy gyanúsnak tünt.

'The truth is that in the past I did not know a lot about Hungarian culture and history. I have relatives in Budapest, but earlier I was not interested in Hungary. I always liked Lake Balaton, Hungarian cuisine and music, but these are the usual things. At school in Romania you could not find out many things about Hungary. What is more, "the neighbor" seemed somewhat evil and suspicious.'

(Dudics 2003: 8).

Emilia admits that previously she was not aware of many aspects of Hungarian culture or history. An important link to the language and the country was that she had relatives living in Hungary, but she does not specify the extent of her relationship with them. In this manner, a significant number of Romanians are exposed to spoken Hungarian to various degrees, not just through bilingual social environments but also as a result of family connections. According to the informant, growing up in a region of Romania where there was bilingual language contact was not sufficient to gain knowledge of Hungarian culture when this is not supported by formal education. Lake Balaton is a major summer tourist resort in Hungary, and was highly popular during the socialist period. Here Emilia makes a difference between liking the "usual things" about Hungary such as touristic attractions and cuisine, and being interested in Hungary itself, including Hungarian language and culture. In other words, Emilia argues that Romanians might visit Hungary as tourists, but still be somewhat "suspicious" about Hungarian language and culture, since at school they have not learned about Hungary. That is, she presents a typical social judgement process. In this case, she first refers to insufficient knowledge, fueled by suspicion, which 
results in an image of evil. Stereotypical and prejudiced images are often perpetuated in this way on a social level. In Romanian historical discourses, Hungarians frequently appear as oppressors; this is a widespread stereotype among Romanians, since history textbooks and the Romanian literature canon read in schools promote this image (Mungiu-Pippidi 1999: 64).

In order to understand Romanian-Hungarian antagonism, it is useful to refer to the history of the region. At the center of the debate is Transylvania, historically the most westernized part of the country where long-term co-residence with Hungarians and Germans "has both Europeanized Romanians and traumatized them on the ethnic question" (Verdery 1996: 126). In the history of Transylvania prior to 1918, Romanians occupied the position of underdog as a part of the Hungarian Kingdom and Habsburg Monarchy.

In the following section, I present a discourse analysis of a TV interview, where the topic is the DSS summer course. The interlocutors are Romanian native speakers who live in Oradea, which lies $70 \mathrm{~km}$ from Debrecen, and where $26 \%$ of the population is Hungarian speaking (Recensământul ... 2011). The following segments are part of a conversation carried out in Romanian on a morning magazine program on regional television. As Myers (2004) points out, the opinions expressed in the television interview are both situated ("enacted in a particular setting of time and place"), and mediated ("disembedded and packaged for use, standardized and reproduced in texts, and linked intertextually to other texts") (2004: 223). The TV interview has a light focus and a loose script in comparison to, for instance, news interviews. The genre is that of a conversational morning program where the interlocutors are on a first-name basis, and the style of talking is very close to everyday casual conversation. The program is broadcast live and seems not to have a script. Following Myers, at the same time "reports of opinions can be particularly effective in conveying conviction and sincerity" (2004: 223). In fact, this light genre programme can be interpreted as more convincing and sincere by the local spectators, since the interlocutors may be seen to be speaking freely, whereas news and other less spontaneous program genres are seen to be strictly scripted and heavily influenced by dominant ideologies in current Eastern Central Europe. In what follows, I will look at the interview and see how the Hungarian learner status is situated and enacted at this particular time, and how it is mediated and packaged on regional Romanian language television. In doing so I refer to the associated intertextual references in order to see how these situated acts of expression are related to the metapragmatic chains.

Doina, a Romanian Hungarian learner, has recently returned from the DSS where she took part in a two week Hungarian language course. She is a middleaged woman, an intellectual interested in architecture and the arts. At the 
beginning of the the interview she states that her motives for studying Hungarian are mostly professional:

(2) Interviewer 1: ai venit astăzi la noi pentru că ți-ai petrecut ultima parte a zilelor sau ultimele zile la Debrecen. într-o tabără (.) să spunem așa nu个

'you came today because you have spent the last days at a camp (.) in Debrecen if we can say like that个'

Doina: da. am îmbinat utilul cu plăcutul (0.4) sau mă rog am practicat ceea ce se cheamă odihnă activă $(0.3)$ mi-am dorit această ieșire dincolo de graniță. pentru că am nevoie tot mai mare de limba maghiară pentru cărțile pe care vreau să le scriu și pentru care @ prima data trebuie să le citesc bibliografia 'yes (.) I have combined the pleasant with the useful (0.4) or I have practiced what they call active relaxation. (0.3) I looked for this trip across the border because I need the Hungarian language more and more for my work (.) for the books that I want to write, and for which first I have to read the bibliography.

Interviewer 1: și presupun că limba maghiară n-o stăpâneai până ce ai mers acolo. (.) cu toate că bihoreancă fiind?

'and I suppose that you had not mastered Hungarian before you went there, (.) even though you are from the Bihor region?

Doina: da bihoreancă. și bunica mea (0.3) era unguroaică 'yes, from Bihor. And my grandmother (0.4) was Hungarian.'

Interviewer 1:

[n-ați vorbit de loc acasă... 'you did not talk at home at all...'

Doina: [ba da ba da. dar la un nivel la care (.) un nivel foa-foarte jos acest házi magyar (.) deci un-un limbaj uzual care nu-mi este [de folos în cea vreau eu să fac]

Doina: $\quad$ 'yes, yes, but yes, but on a ve-very lo-low level this (0.3) domestic Hungarian so, the everyday language that [is not useful for me for what I want to do]'.

Interviewer 1: [cel pe care-l înveți în curtea blocului de la copii, așa-i?

'[the one that you learn in the courtyard in front of the block of flats from the children, is it?' 
Doina: [exact. exact. exact.

'[exactly. exactly. exactly.'

Interviewer 1: [haza, néni (0.3) categoric. sunt cuvintele]

'[home, auntie (0.3) absolutely, the words.]'

Doina:

[care sun mai c-al tău și nu-l uiți niciodată]

'[The ones are like your own and you never forget.]'

Interviewer 1: categoric.

'absolutely.'

The interviewer asks Doina about her time spent in Debrecen. It is noteworthy that here she uses the Hungarian version of the name of the city, which is significant because Debrecen has a Romanian equivalent, Debrețin. In the later sequences the Hungarian spelling alternates with the Romanian pronunciation.

First, the idea of tourism and language learning appears: the notions of "active relaxation" and the "combination of the pleasant with the useful" are introduced by Doina. In Doina's account, cultural, educational, and touristic aims go hand in hand. She explains that she took part in a language course because she needs the language for professional reasons, so her motivation is instrumental in this first utterance. She clarifies her position as that of an intellectual who needs the language for more than mere quotidian concerns. The formulation "outing across the border" is typical and suggests that cross border travel is very common now. The next sequence in the conversation is significant in terms of the emergence of language identity negotiation. Norton (2000) cautions us that learners should be viewed as social beings in sites of struggle and with multiple and changing identities. In the present context, too, it is important to point to the distinction between learning and language education. That is, Romanians can learn Hungarian in many ways but it is rarely taught in the classroom.

Doina presents herself as an intellectual; she creates an intellectual identity for herself in the ongoing interaction with the interviewer and in relation to the audience. At the same time, we see that the interviewer is not satisfied and demands further clarification in relation to Doina's presence in the Hungarian course of the DSS, asking Doina about her previous knowledge of Hungarian: "I suppose that you had not mastered Hungarian before you went there (.) even though you are from the Bihor region?” By posing this question, the interviewer claims that inhabitants of the Romanian Bihor are exposed to Hungarian. In this frame of reference Doina's presence on the course requires explanation. The questions themselves suggest that people from Bihor take it as fact that they know some Hungarian precisely because they are from this multilingual region. 
When remarking that Doina attends the course "even though that you are from Bihor?" the interviewer implies that Romanians from Bihor can speak some Hungarian. A reason for the lack of Hungarian knowledge would be that one was not brought up in the region. We can clearly observe how the interviewer challenges Doina and suggests a Hungarian translanguage (see e.g. Garcia 2007) speaker identity based on her situated regional indentity. It is in the interaction, prompted by the interviewer to clarify and interpret the complex motifs of attending a Hungarian course, that another identity emerges for Doina, that of a heritage language learner, when she states that her grandmother was in fact Hungarian. The interviewer quickly inserts an overlapping question: "and you did not talk at home?" That is, not speaking Hungarian with an ethnic Hungarian grandmother would be another logical and possible explanation for why one would go and take part in a Hungarian course. Doina does not allow her to finish the sentence, but hastily adds that she knew házi magyar (domestic Hungarian). Házi magyar is associated with a vernacular, very rudimentary level of language use. However, that is of no use to her, since she wants to read Hungarian books. Thus, she went to the DSS to attend a formal language course. In the next exchange the interlocutors work out together the meaning of házi magyar.

It is Doina who introduces the term házi magyar, in Hungarian, and also gives the explanation that she means the "everyday language". The interviewer contributes with more examples in Hungarian haza ("home"), néni ("auntie"). She does not translate these words into Romanian. There is a significant number of other Hungarian words used in other parts of the interview which are not translated into Romanian for the audience either. That is, they are considered familiar to the audience: some of them are basic adjectives, adverbs, or denote everyday objects or places: ez (this), jó (good), jól van (fine), nagyon szép buli (very beautiful party), házi buli (house party), ez a kutya (this dog), kollégium (student dorm); others are Hungarian realia: babgulyás (Hungarian Bean Goulash Soup), csárdás (traditional Hungarian folk dance), which have similar forms in Romanian too. It is noteworthy, however, that the interlocutors use the Hungarian pronounciation in this context. We see a heteroglossic language ideology operating here. The speakers assume that the audience is also familiar with these expressions. The excerpt shows that Romanians possess varying competencies in Hungarian. We can find heteroglossic speakers who have a survival, or at least "anecdotic" or "translinguistic" (e.g. Garcia 2007) knowledge of Hungarian because they come from an area in Romania where Hungarian is present in the environment (most of Transylvania). This excerpt shows that there are similarities between heritage language learners and those who (perhaps passively) learnt the language from their environment. This exchange shows 
that Romanians may position themselves differently to those learners who first encounter the language as adults.

The interviewers and the informant are in agreement about the nature of language acquisition. They agree that the words in question "are like your own and you never forget them". That is, they agree that one never forgets words learnt during childhood. In the next excerpt, the interlocutors discuss participation in the DSS that prompts cultural reflexivity.

The discussion continues on the architecture of the University of Debrecen and the pleasant surroundings of the campus area:

(3) Interviewer 1: ăhăm, da imperiul austro-ungar

'ahm the Austro-Hungarian Empire.'

Interviewer 2: ha, ha

'ha, ha.'

Doina: $\quad$ exact exact, și nu numai e o arhitectură internațională cu torțe, o să vedem imediat printre imagini e foarte binegândită

Doina: 'exactly, exactly, and not only (.) is it an international architecture with torches. We will see them in the following images well throughout.'

Interviewer 1: putem să trecem la imaginile următoare 'we can move on to the following photos.'

Doina: $\quad$ parcul. este un parc foarte mare cu multă verdeață cu multe spații în care poți să te reculegi să citești și lumea chiar face acest lucru

Doina: 'the park (.) it's a very big park with a lot of green, a lot of space to relax and read and the people do this thing.'

Interviewer 1: este foarte interesant că discutăm despre un Debrețin în care 90\% din orădeni cu siguranță au fost și n-au văzut niciodată aceste locuri.

'it is very interesting to talk about a Debrețin where 90 per cent of the Oradeans have been to and they have never seen these places.'

Doina: $\quad$ iți mulțumesc XX chiar acesta a fost și intenția mea să deschid puțin o mică poartă spre o lume în sine (0.2) care e ăm, are identitate.

'thank you. XX this was my intention to open a small gate towards a world in itself (.) one that has mhm identity'

Interviewer 1: este vorba despre partea culturală a orașului.

'it is about the cultural side of the city' 
Doina: culturală informațională, de propagandă, dar foarte inteligent făcută. Acest lucru îmi place.

'cultural informational, of propaganda, but done very intelligently (.) I like this thing'

Tourism plays a center role in the SA framework and the present context too (see Kinginger 2009: 12). The text shows strong intercultural awareness and selfreflection. Both interviewer and interviewee are in possession of "mobility capital" (Murphy-Lejeune 2002: 51) and border crossing has become a mundane, demystified activity for them. At the same time, a clear distinction needs to be made between language learning for tourist purposes, where comprehensionfor-conversation is of primary importance (Phipps 2007: 100), and the academic context of learning a language, where the main focus is on literacy, reading, and writing. For the informants, the intellectual type of this latter kind of language learning seems to carry more relevance. As pointed out earlier, Romanians living in the border regions already have a touristic survival level of Hungarian adequate for transborder trade and trips.

In this section, the discussion is supported by images that are shown to the television viewers. The first image is that of the university building, which is an important icon and branding element on virtually all of the promotional materials (brochures, posters, etc.) of the DSS. Doina, a specialist in the field, praises the well-positioned and impressive central building of the University of Debrecen.

When looking at the building, Interviewer 1 states that she is unfamiliar with these parts of the city, despite the fact that she often goes to Debrecen. The fact that she uses the plural in her remarks is significant, giving the impression that she assumes the voice of others while at the same time forming an in-group: "we often go to Debrecen, and I have never seen it (.) I think we were not curious". Upon learning that her interterlocutors are not familiar with the university Doina insists that there are also other sites worth visiting. The interviewer intends to speak on behalf of a larger group, perhaps for Romanians in general.

In the interview, Doina positions herself as an enthusiastic Hungarian learner to which the interviewer reacts with ironic comments. They stage language learning in the historical frame by evoking discourses of patriotism intertwined with touristic activities and consumption culture. The discussion about the building continues, and Interviewer 1 and Doina agree that it dates back to the "years of power", the times of the "Austro-Hungarian Empire". That is, the historical period of Hungarian dominance has relevance in the present Romanian discourses as well. 
The interviewer reiterates her observation that it was very interesting to learn that although " $90 \%$ of people from Oradea have visited [Debrețin], ... they have never seen these places”. This sentence makes it clear that by using the previous plural pronoun she had in mind the overwhelming majority of the people of Oradea. She also adds the explanation that, in spite of their familiarity with the mundane aspects of daily life, "It is the cultural side of the city" that is unfamiliar to these visitors. That is, the intellectual learner type considers that there is a gap between the everyday practices of tourism, shopping, and the cultural dimensions of the city. She implies that most Romanians are not exposed to the cultural dimension even though they may have visited the city.

(4) Doina: $\quad$ Pe acest model aș vrea ca (.) limba și cultura românească (.) și evident cu nuanțele locale, de care ne tot mândrim și facem atât caz (.) aș vrea de felul aceasta să fie promovate (.) Civilizat inteligent ăh... într-un mod subtil ăh (.) inoculate (.) sau mă rog sugerate anumite tendințe (.) dar oricum pleci de acolo crezând, sau fiind convins că tu ai decis să faci această opțiune (.) poate că nu-i chiar așa poate că este o ușoară manipulare, n-are importanță, dar e făcută bine e făcută cu bun simți (.) pentru că tu vorbeai nu de mult de acest bun simț

'based on this model I would like to present the (.) Romanian language and culture (.) and, certainly also present the local nuances that we take so much pride in (.) I'd like this way to be promoted (.) in a civilized, intelligent way er ... and in a subtle er (.) inoculation (.) or well favouring certain tendencies (.) but anyway, you leave there believing, or being convinced that you yourself made a choice (.) it may be that it is not all like that and there is a slight manipulation, it doesn't matter, but it is done with decency, because you spoke of decency earlier'

Interviewer2: cred că ești o visătoare aici la capitolul acesta

'I think you are a dreamer in this chapter here'

Interviewer1: și ca să observe și vecinii noștri că nu avem deloc conflicte (.) apreciem pe cultura pe care ungurii au prezentat-o (.) Doina este o dovadă vie aici (.) a venit și ne-a povestit numai lucruri bune, iar noi suntem încântați de ceea ce am auzit

'and so that our neighbors could see that we have no conflicts at all (.) we appreciate the culture that the Hungarians 
presented (.) Doina is the living proof here (.) she came and told us about only good things, and we are delighted by what we heard'

Doina finds that the DSS model is an example to follow, even for similar programs teaching Romanian, "certainly also present the local nuances that we take so much pride in". Here she refers to the regional particulars of the multilingual Bihor region, which the informant considers people are proud of. In this utterance, Doina presents a favourable attitude not only towards language learning, but towards the model of the DSS too.

Towards the end of the interview, Doina states that the aim of the course is more than just teaching language. She says that perhaps there is "there is a slight manipulation, it doesn't matter, but it is done with decency”. It seems that the DSS has remained true to its original goal, formulated in the 1930s. Némedi sums it up in the following way: "the fundamental objective, namely to acquaint the participants with Hungary and convert them into friends of the nation and culture - including Hungarians in the neighboring countries, civilization and official policies, remained carefully concealed" (1988: 181). As was demonstrated, this objective has also remained quite constant throughout the decades, and while the mechanisms have changed, the experience of the participants shows that the formula still works, at least for the intellectual learner type. The language learner in the second interview suggests that through participation at a summer course one could gain a broader intellectual horizon and contest formerly upheld stereotypes. As opposed to this, Interviewer 2 does not share her views and retorts: "I think you are a dreamer in this respect”. The editor's remarks and critique serve to counterbalance the sometimes enthusiastic intellectual type language learner. In the first interview excerpt, which is in fact an autobiographical mini narrative, the interviewee reflects upon her earlier attitudes. It was evident that stereotypes played a role in the development of the language learners' attitudes towards the Hungarian language. In the second interview excerpt, the intellectual learner suggests that the underlying attitudes could be changed by taking part in language training programs - in this case at the DSS. The reactions of her interlocutors, however, suggest that this reconciliatory approach of the intellectual learner is not universally shared. Her arguments are not seen as convincing.

At the same time, Interviewer 2 feels it necessary to point out that this discussion could serve to show openness towards the neighbor. Again, she uses the first person plural, so we can assume that she intends to voice her opinion on behalf of Romanians in general: "and so that our neighbors could 
see that we have no conflicts at all (.) we appreciate the culture that the Hungarians presented (.) Doina is the living proof here (.) she came and told us about only good things, and we are delighted by what we heard". The learner presented belongs to the intellectual learner type. The analysis also reveals that, beside the instrumental motives, the informant can be considered a heritage learner, and that the interlocutors are in agreement about the nature of language learning in a bilingual area where the language is used by a Hungarian-speaking minority. In brief, Hungarian is not a foreign language for most Romanians.

From the interview we learn about the language ideologies of Romanians, namely, how they talk about using and learning Hungarian among other Romanians (interviewers and spectators). The arising discourses are framed against a historical background and, on the part of the interviewers, to some extent against traditional Romanian nationalism.

\section{Conclusion}

Ideas about language are developed and circulated on many planes. Language teaching is just one of these. In East Central Europe, ethnolinguistic nationalism and language ideology have been entrenched. For the most part, twentieth century Hungarian elites have favored the "cultural nation" definition of Hungary while the neighboring nations in East Central Europe have emphasized the importance of the "civic or political nation" stance (e.g. Gal 2008). Such a conceptual antagonism seldom fosters the learning of a historical minority language by the dominant ethnicity. At the same time, the foremost aim of Hungarian cultural politics was to maintain links with Hungarians in the kin states, and for a long time until recently there were but timid attempts to promote the study of Hungarian by the members of neighboring titular groups. That is, in a historically hostile transnational climate, the learning of historical minority languages has little support.

Following the change of regime (1989), the suggested source of motivation was increased interest towards the region and Hungary. The 1990s were the times when, after the regime change and the opening up of the region for the free movement of ideas and people, Hungary with its somewhat exotic language became an available and interesting destination. The number of foreign language learners, most of whom arrived from western countries, reached record figures. Even though Romanian intellectuals were perceived to be involved in the emerging East-Central European dialog to a lesser degree, Romanians also became more familiar with Hungary in the form of border and transit travel. The 
number of Romanian participants at the DSS courses grew steadily. The period following the early 1990s was also subordinated to pragmatic choices about the possibilities and marketability of Hungarian courses. This is the time when the teaching of Hungarian as a second language became more pragmatic. Currently, in the context of globalization and European integration, the free circulation of ideas and material goods has created challenges as well as offering new opportunities to the DSS. The DSS continues to capitalize on its tradition and experience of 85 years in its course advertisements. At the same time, the institution searches for new ways to best serve its function as as it began to offer its courses to potential participants in new markets in Hungary and abroad, setting up successful collaborations to run courses in the United States, the Netherlands, and in neighboring Romania. This new venture proves that the DSS viewed the neighboring countries as potential markets and now wishes to offer Hungarian courses to the dominant language speakers of those neighboring countries. European projects and funding have brought new groups of Romanians learning Hungarian to Debrecen. In this way, the formerly intellectual learner type with academic goals is now accompanied by a variety of other learner types.

It is evident that a language ideology which creates hierarchies between vernacular and formal language learning is in operation. The intellectual learner type may become interested in Hungarian language and culture. As illustrated, the motivations of the learner may be manifold: personal, professional, or instrumental. Furthermore, the interview shows that the Romanian learners need to negotiate their way through stereotypes and prejudice about Hungary and the Hungarian language.

A further result of the study is that it casts light on the diversity of language learners within this group. Romanians may be heritage learners or may have surpassed the basic level in Hungarian by picking up different elements from the environment. They are much less likely to need mere survival skills and are already able to perform simple touristic or border crossing tasks in the language. That is, Romanians from Transylvania are unlikely to study to achieve "the art of linguistic survival" (Phipps 2007). This indicates that different types of instruction might be needed by those who come from areas where Hungarian is present in the environment. The interviews also provide a good example of instances where long held language ideologies change throughout life (see Woolard 2013; Pujolar and Gonzales 2013), in our case contact with the language at the DSS, and thus, changed requirements for language ideological reorientation.

The important role of language learning in harmonious coexistence and mutual understanding alongside the concern for the development of intercultural competence has been a recurrent theme in European SA research. My interview discourse data suggests that, in order for Hungarian language learning 
to appeal to larger groups of people in the neighboring cultures, it would seem to be necessary to first change deeply rooted and mutually shared historical prejudices.

The present article combined historical approaches with language ideologies by focusing on an institution offering language education. Language ideologies were presented in the larger historical discourses, contemporary documents, and discourse analysis of interview data. In 2012, DSS celebrated 85 years of existence. My examination indicates that progress in fostering tolerance between cohabitating and neighboring ethnicities is possible, even though the DSS has not always been immune to the ideologies that have made this difficult. However, recent developments show that the teaching of Hungarian in Debrecen to voluntary learners of neighboring cultures has the significant potential to contribute to a better mutual understanding in East-Central Europe.

\section{Symbol Key}

\section{Transcription symbols}

$\begin{array}{ll}= & \text { latched to the previous talk } \\ (0.4) & \text { measured pause } \\ \text { (.) } & \text { micro-pause less than } 0.2 \mathrm{sec} \\ \text { @ } & \text { change of voice } \\ \text { well- } & \text { cut off of the preceding sound } \\ ? & \text { question intonation } \\ \text {, } & \text { continuing intonation } \\ \text {. } & \text { falling intonation } \\ \uparrow & \text { rising intonation } \\ \text { [] } & \text { overlapping talk } \\ \text { italics } & \text { an utterance in Hungarian } \\ \text { XX } & \text { masking of proper names }\end{array}$

Funding: I gratefully acknowledge funding for this research through the University of Jyväskylä, CIMO, and Svenska Kulturfonden awarded to me in 2012-13.

\section{References}

Azkue, Jokin \& Perales, Joshua. 2005. The teaching of Basque to adults. International Journal of the Sociology of Language 174. 73-83. 
Atkinson, Dwight. 2005. Situated qualitative research and second language writing. In Paul K. Matsuda \& Tony Silva (eds.), Second language writing research: Perspectives on the process of knowledge construction, 49-64. Mahwah, NJ: Erlbaum.

Blackledge, Adrian. 2002. 'What sort of people can look at a chicken and think dofednod?': Language, ideology and nationalism in public discourse. Multilingua 21. 197-226.

Brogden, Lace Marie. 2009. Francois, f/Fransask-qui? Franco-quoi? Constructions identitaires d'un enseignant en formation en situation linguistique minoritaire. Canadian Modern Language Review/La Revue Canadienne des Langues Vivantes (CMLR) 66(1). 73-99.

Block, David. 2007. Second language identities. London: Continuum.

Blommaert, Jan. 2006. Language ideology. In Keith Brown (ed.), Encyclopaedia of language and linguistics, 510-522. Oxford: Elsevier.

Blommaert, Jan \& Dong, Jie. 2010. Ethnographic fieldwork: A beginner's guide. Bristol: Multilingual Matters.

Cavagnoli, Stefania \& Francesca Nardin. 1999. Second language acquisition in South Tyrol: Difficulties, motivations, expectations. Multilingua 18. 17-45.

Dudics, Emese. 2003. Milyen nyelven érzünk? [In what language do we feel?] Nyári Egyetem (1). 8.

Gal, Susan. 2006. Language, its stakes and its effects. In Robert E. Goodin \& Charles Tilly (eds.), The Oxford handbook of contextual political analysis, 376-391. Oxford: Oxford University Press.

Gal, Susan. 2008. Hungarian as a minority language. In Guus Extra \& Durk Gorter (eds.), Multilingual Europe: Facts and policies, 207-232. Berlin: Mouton de Gruyter.

Gal, Susan. 2011. Polyglot nationalism. Alternative perspectives on language in 19th century Hungary. Langage Et Société 136 (2). 31-34.

Garcia, Ofelia. 2007. Foreword. In Sinfree Makoni \& Alastair Pennycook (eds.), Disinventing and reconstructing languages, xi-xv. Clevedon: Multilingual Matters.

Geertz, Clifford. 2000 (1973). The interpretation of cultures. New York: Basic Books.

Hashimoto, Hiroko. 1993. Language acquisition of an exchange student within the homestay environment. Journal of Asian Pacific Communication 4(4). 209-224.

Heller, Monica. 2001. Discourse and interaction. In Deborah T. Schiffrin \& Heidi E. Hamilton (eds.), The handbook of discourse analysis, 250-264. Oxford: Blackwell.

Heller, Monica. 2007. Distributed knowledge, distributed power: A sociolinguistics of structuration. Text \& Talk 27 (5-6). 633-653.

Heller, Monica. 2008. Doing Ethnography. In L. Wei \& M. Moyer (eds.), The Blackwell Guide to Research Methods in Bilingualism and Multilingualism, 249-262. Oxford: Blackwell.

Heller, Monica. 2011. Paths to post-nationalism: A critical ethnography of language and identity. New York: Oxford University Press.

Jaworska, Sylvia. 2009. Border crossings: The German language in Poland: The eternal foe and the wars on words. In Jenny Carl \& Patrick Stevenson (eds.), Language, discourse and identity in central Europe: The german language in a multilingual space, 51-72. Basingstoke: Palgrave Macmillan.

Kádár, Edit. 2008. Az erdélyi nyelvészeti kutatások jelenlegi helyzete [The currents state of Transylvanian linguistic research]. Kolozsvár: Kolozsvári Akadémiai Bizottság Nyelvtudományi Szakbizottság. www.sztanyi.ro/download/ErdelyiNyelveszetiKutatasok. pdf (accessed 18 November 2014).

Kinginger, Celeste. 2009. Language learning and study abroad: A critical reading of research. Basingstoke: Palgrave Macmillan. 
Kiss, Attila. 2012. Hungarian as a second language in Oradea/Nagyvárad: Cultural reflexions and language ideologies. In Monok István (ed.), Transition and difference: Hungarian perspectives on east and central European studies. Symposium for PhD Students, $7^{\text {th }}$ International Congress of Hungarian Studies, Cluj-Napoca, 2011, 279-293. Budapest: International Association for Hungarian Studies.

Kiss, Attila. 2013. A magyar mint második nyelv tanításának nehézségei és sikerei Nagyváradon. [The difficulties and successes of teaching Hungarian in Oradea]. In Orsolya Nádor (ed.), THL2: The Journal of Teaching Hungarian as a Foreign Language (1-2). 97-115.

Laihonen, Petteri. 2008. Language ideologies in interviews: A conversation analysis approach. Journal of Sociolinguistics 12 (5). 668-693.

Lantolf, P. James \& Aneta Pavlenko. 2001. (S)econd (L)anguage (A)ctivity Theory: Understanding second language learners as people. In Michael P. Breen (ed.), Learner contributions to language learning: New directions in research, 141-58. London: Longman.

Lawson, Max. 1995. The International People's College, Helsingor, Denmark: Seven decades of peace education. Peace education miniprints 71 . http://search.proquest.com/docview/ 62615859? accountid $=11774$ (accessed 18 November 2014).

Long, Michael. 1997. Construct validity in SLA research: A response to Firth and Wagner. Modern Language Journal 81 (3). 318-323.

Mar-Molinero, Clare. 2006. The European linguistic legacy in a global era: Linguistic imperialism, Spanish and the Instituto Cervantes. In Clare Mar-Molinero \& Patrick Stevenson (eds.), Language ideologies, policies and practices: Language and the future of Europe, 58-76. Basingstoke: Palgrave Macmillan.

Marton, Enikő \& László Vincze. 2011. Tanuljuk-e a másik nyelvet?: Megértés, attitűdök és az egymás nyelve iránti érdeklődés erdélyi magyar és román fiatalok körében [Are we studying each others' languages?: Comprehension, attitudes and interest towards each others' language among Hungarian and Romanian youth]. Modern Nyelvoktatás 17(2-3). 101-107.

May, Stephen. 2012. Language and minority rights: Ethnicity, nationalism and the politics of language. New York: Routledge.

McEwan-Fujita, Emily. 2010. Ideology, affect, and socialization in language shift and revitalization: The experiences of adults learning Gaelic in the Western Isles of Scotland. Language in Society 39: 27-64.

Menard-Warwick, Julia \& Deborah Palmer. 2012. Bilingual development in study-abroad journal narratives: Three case studies from a short-term program in Mexico. Multilingua 31 (4). 381-412.

Molnár, Szabolcs. 2000. Megjegyzések a hungarológiáról Bukarestből [Notes about Hungarian studies from Bucharest], 210-214. In György Tverdota (ed.), Hungarológia, 2-3. Budapest: Nemzetközi Hungarológiai Központ.

Mungiu-Pippidi, Alina. 1999. Tansilvania subiectivă [Subjective Transylvania]. București: Humanitas.

Murphy-Lejeune, Elisabeth. 2002. Student mobility and narrative in Europe: The new strangers. New York: Routledge.

Murvai, Olga. 2010, 2010-08-06. Búvárkodás szavak között. Krónika. www.kronika.ro/index. php?action $=$ open\&res $=41000$ (accessed 10 May 2012).

Myers, Greg. 2004. Matters of opinion: Talking about public issues. Cambridge: Cambridge University Press. 
Némedi, Lajos. 1988. Emlékek, adatok és gondolatok: A Debreceni Nyári Egyetem hatvan esztendejéröl 1927-1987 [Recollections, data and thoughts: About the 60 years of the Debrecen Summer School]. Debrecen: Tudományos Ismeretterjesztő Társulat.

Norton, Bonny. 2000. Identity and language learning: Gender, ethnicity and educational change. Harlow: Longman.

Péntek, János. 2002. Örökség és kihívás. Az erdélyi Magyar nyelvtudomány a század- és ezredfordulón [Heritage and challenge. Transylvanian Linguistics at the turn of the century and the millenium]. In Vilmos Tánczos, Gyöngyvér Tőkés, István Moldován \& Andrea Góczán (eds.), Tizenkét év: Összefoglaló tanulmányok az erdélyi Magyar tudományos kutatások 1990-2001 közötti eredményeiröl. I, 15-50. Cluj-Napoca/Kolozsvár: Scientia.

Phipps, Alison. 2007. Learning the arts of linguistic survival: Languaging, tourism, life. Clevedon: Channel View Publications.

Pujolar, Joan \& Gonzales, Isaac. 2013. Linguistic "mudes" and the de-ethnicization of language choice in Catalonia. International Journal of Bilingual Education and Bilingualism, 16 (2), 138-152.

Recensământul populației și al locuințelor 2011. http://www.recensamantromania.ro/rezultate2/ (accessed 18 November 2014).

Résztvevők megoszlása országok szerint. 1996. [Distribution of participants according to countries]. Nyári Egyetem, 1996 (2). 6.

Résztvevők országok szerint. 1999. [Participants by countries]. Nyári Egyetem, 1999 (2). 13.

Rindler Schjerve, Rosita \& Eva Vetter. 2012. European multilingualism: Current perspectives and challenges. Bristol: Multilingual Matters.

Scollon, Ronald \& Suzanne Scollon. 2004. Nexus analysis: Discourse and the emerging internet. London: Routledge.

Szilvási, Andrea. 2011. A magyar mint idegen nyelv Szlovákiában [The Hungarian language in Slovakia]. In Katalin Misad \& Zoltán Csehy (eds.), Nova Posoniensia, 99. Pozsony/ Bratislava: Szenczi Molnár Albert Egyesület \& Kalligram.

Spolsky, Bernard. 2011. Second-language learning. In Joshua A. Fishman \& Ofelia García (eds.), Handbook of language and ethnic identity, 172-185. Oxford: Oxford University Press.

Talburt, Susan \& Melissa A. Stewart. 1999. What's the subject of study abroad? Race, gender and "living culture". Modern Language Journal 83 (2). 163-75.

Ten Have, Paul. 2004. Understanding qualitative research and ethnomethodology. London: Sage Publications.

Verdery, Kathrine. 1996. What was socialism and what comes next? Princeton: Princeton University Press.

Woolard, Kathrine \& Schieffelin, Bambi. 1994. Language ideology. Annual Reviews Anthropology 23, 55-82.

Woolard, Kathrine. 2013. Is the personal political? Chronotopes and changing stances toward Catalan language and identity. International of Bilingual Education and Bilingualism, 16 (2), 210-224.

Wünsch, Danielle. 2004. Einstein et la Commission internationale de coopération intellectuelle. Revue d'histoire des sciences. Tome 57(2). 509-520. 